\title{
Magnetic Nanocomposite Material Containing Chitosan Polymer Used in Wastewater Depollution Processes
}

\author{
CRISTINA ILEANA COVALIU*, ECATERINA MATEI, OANA STOIAN, \\ GIGEL PARASCHIV \\ University Politehnica of Bucharest, 313 Splaiul Independentei, 060042, Bucharest, Romania
}

\begin{abstract}
The aim of this paper was to present the synthesis, characterization and application of the $\mathrm{Fe}_{3} \mathrm{O}_{4}$ - chitosan composite as potential adsorbent for removing lead ions from industrial wastewater. The nanocomposite nanomaterial was characterized by XRD and SEM analyzes. The influence of some parameters ( $\mathrm{pH}$ of wastewater, lead ions concentration and dose of $\mathrm{Fe}_{3} \mathrm{O}_{4}$ - chitosan absorbent) upon the efficiency of wastewater treatment were investigated. The Pb (II) ions concentrations in wastewater were 0.5, $1,1.5$ and $2 \mathrm{mg} / \mathrm{L}$. The amounts of $\mathrm{Fe}_{3} \mathrm{O}_{4}$ - chitosan nanocomposite adsorbent tested were 0.05, 0.1 and $0.2 \mathrm{~g}$. In some experimental conditions, $\mathrm{Fe}_{3} \mathrm{O}_{4}$ - chitosan nanocomposite adsorbent leaded to obtaining of $100 \%$ wastewater treatment efficiency.
\end{abstract}

Keywords: magnetite, chitosan, composite, lead ions removal, XRD, SEM

\section{Introduction}

Eventhough magnetite nanomaterial has an important role in many fields, the uncoated nanoparticles may have some disadvantages, such as the fact that they easily form large aggregates [1] or that they are not selective, thus is essential to coat them with an adequate coverage for overcoming such limitations [2]. The coating of the magnetic nanoparticles surface with various compounds may improve their chemical and mechanical properties, stabilizes and determines their final shape, increases the dispersion capacity in various solvents and provides functional groups for the attachment of specific ligands or metals, so that coating can become an adapting method of magnetic particles properties to subsequent applications [3].

Chitosan is the alkaline hydrolytic derivative of chitin [4], a renewable resource that is currently being intensively explored for its applications in the pharmaceutical, cosmetic, biomedical, biotechnological, agricultural, food and non-food industries [5]. This special polymer has emerged as a new class of materials with extremely sophisticated functions due to their excellent biocompatibility, versatile biological activity and complete biodegradability in combination with very low toxicity.

Materials containing chitosan in combination with magnetite $\left(\mathrm{Fe}_{3} \mathrm{O}_{4}\right)$ are used in various applications such as:

- in biomedical field to treat cancer by hyperthermia. For biomedical applications, such as hyperthermia, $\mathrm{Fe}_{3} \mathrm{O}_{4}$ nanoparticles must have a high saturated magnetization, uniform particle size and superparamagnetism [6,7].

- in environmental engineering field, for wastewater treatment, materials containing $\mathrm{Fe}_{3} \mathrm{O}_{4}$ - chitosan may be used to remove heavy metals from wastewater [8].

The pollution with toxic metals is a serious problem that threatens human health. Heavy metal ions such as $\mathrm{Pb}$ (II), $\mathrm{Cd}$ (II), $\mathrm{Hg}$ (II) and $\mathrm{Ni}$ (II) are toxic and carcinogenic at relatively low concentrations. They are not self-degrading and can accumulate in living organisms, causing severe disorders and diseases. To remove heavy metal ions from various media, techniques such as precipitation [9], adsorption [10], ion exchange [11], reverse osmosis [12], electrochemical treatments [13], membrane separation [14], coagulation [15], flotation [16], oxidation [17] and biosorption processes [18] are widely used.

*email: ecaterinamatei@yahoo.com 
These conventional techniques are expensive and have significant disadvantages, such as the production of sludge or waste from metal bearings, incomplete metal disposal and secondary waste removal. For these reasons, it is necessary to develop economic and ecological methods for wastewater treatment. Adsorption is an attractive process, given its efficiency and ability to treat wastewater containing heavy metals. In recent decades, adsorption has gained importance as an efficient treatment and separation technique used in wastewater treatment and low-cost adsorbents are becoming the focus of many investigations on the removal of heavy metals from water [10]. Chitosan in combination with magnetite can be considered a good adsorbent, having the potential to remove toxic metal ions from wastewater.

Nanomaterials composed of magnetite and chitosan have been researched in order to remove some heavy metal ions from wastewater such as $\mathrm{As}$ (V), $\mathrm{Cr}$ (VI), $\mathrm{Cu}$ (II), $\mathrm{Pb}$ (II), $\mathrm{Cd}$ (II), $\mathrm{Ni}$ (II), some examples being presented in Table 1.

Table 1. Nanocomposites used to remove heavy metal ions from wastewater

\begin{tabular}{|c|c|c|c|c|c|c|c|c|c|}
\hline Adsorbant & Pollutant & $\begin{array}{c}\text { Quantity of } \\
\text { adsorbant } \\
{[\mathrm{g} / \mathrm{L}]}\end{array}$ & $\begin{array}{c}\begin{array}{c}\text { Solution } \\
\text { volume } \\
{[\mathrm{mL}]}\end{array} \\
\end{array}$ & pH & $\begin{array}{l}\text { Contact } \\
\text { time [min] }\end{array}$ & $\begin{array}{l}\text { Speed } \\
{[\text { rpm }]}\end{array}$ & $\begin{array}{c}\text { Initial } \\
\text { concentration } \\
{[\mathrm{mg} / \mathrm{L}]}\end{array}$ & $\eta[\%]$ & Ref. \\
\hline $\begin{array}{c}\text { Chitosan coated } \\
\text { magnetite } \\
\text { nanoparticles }\end{array}$ & As $(\mathrm{V})$ & 1.00 & 100 & $3-4$ & 140 & 160 & 2.00 & $\approx 100.00$ & [19] \\
\hline \multirow{3}{*}{$\mathrm{Fe}_{3} \mathrm{O}_{4} @$ chitosan } & \multirow{3}{*}{$\mathrm{Cr}(\mathrm{VI})$} & م & \multirow{3}{*}{50} & \multirow{3}{*}{2} & \multirow{3}{*}{360} & \multirow{3}{*}{250} & 5.00 & 100.00 & \multirow{3}{*}{ [20] } \\
\hline & & 0.40 & & & & & 300.00 & 59.74 & \\
\hline & & 0.025 & & & & & 5.00 & 34.20 & \\
\hline \multirow{5}{*}{$\begin{array}{l}\text { Nano magnetite } \\
\text { chitosan }\end{array}$} & $\mathrm{Cu}$ (II) & \multirow{5}{*}{2.00} & \multirow{5}{*}{-} & 5.5 & \multirow{5}{*}{140} & \multirow{5}{*}{200} & \multirow{5}{*}{20.00} & $\approx 95.00$ & \multirow{5}{*}{ [21] } \\
\hline & $\mathrm{Cr}(\mathrm{VI})$ & & & & & & & $\approx 94.00$ & \\
\hline & $\mathrm{Pb}$ (II) & & & 6.5 & & & & 94.00 & \\
\hline & $\mathrm{Cd}$ (II) & & & 7 & & & & $\approx 93.00$ & \\
\hline & $\mathrm{Ni}$ (II) & & & 6.5 & & & & $\approx 91.00$ & \\
\hline \multirow{4}{*}{$\begin{array}{l}\text { Chitosan } \\
\text { functionalized } \\
\text { magnetic nano- } \\
\text { particles }\end{array}$} & \multirow{4}{*}{$\mathrm{Pb}$ (II) } & \multirow{3}{*}{1.00} & \multirow{4}{*}{100} & 2 & \multirow{3}{*}{60} & \multirow{4}{*}{120} & \multirow{4}{*}{100} & $\approx 30.00$ & \multirow{4}{*}{ [22] } \\
\hline & & & & 6 & & & & 99.26 & \\
\hline & & & & 8 & & & & $\approx 90.00$ & \\
\hline & & 1.60 & & 6 & 45 & & & 99.48 & \\
\hline
\end{tabular}

This study completes data from the scientific literature on magnetic nanocomposites such as $\mathrm{Fe}_{3} \mathrm{O}_{4}$ - chitosan composite regarding testing for lead ions removal from wastewater. The $\mathrm{Pb}$ (II) ions concentrations in wastewater were $0.5,1,1.5,2 \mathrm{mg} / \mathrm{L}$, whereas the amounts of $\mathrm{Fe}_{3} \mathrm{O}_{4}$ - chitosan nanocomposite tested for wastewater treatment were: $0.05,0.1,0.2 \mathrm{~g}$. During the investigations some experiments leaded to $100 \%$ yield of wastewater treatment.

\section{Materials and methods}

Nanocomposite containing magnetite and chitosan were prepared as follows: $50 \mathrm{~mL}$ of solution containing $0.5 \mathrm{~g}$ of chitosan dissolved in water and $5 \mathrm{~mL}$ of $\mathrm{CH}_{3} \mathrm{COOH}$ was homogenized with $0.6 \mathrm{~g}$ $\mathrm{Fe}_{3} \mathrm{O}_{4}$ for $2 \mathrm{~h}$ at $60^{\circ} \mathrm{C}$. The was synthesized according to the scientific literature [23] Then, the final composite material $\left(\mathrm{Fe}_{3} \mathrm{O}_{4}\right.$ - chitosan) was separate by centrifugation. Structure and crystallinity of the nanocomposite was investigated by a X-ray diffractometer. A Panalytical X`Pert PRO MPD diffracto- 
meter with high-intensity $\mathrm{Cu} \mathrm{K} \alpha$ radiation $(\lambda=1.54065 \AA)$ and $2 \theta$ range from $10^{\circ}$ to $90^{\circ}$ was used to obtain XRD patterns.

Morphology of $\mathrm{Fe}_{3} \mathrm{O}_{4}$ - chitosan composite was investigated using a Quanta INSPECT F scanning electron microscope equipped with FEG at a resolution of $1.2 \mathrm{~nm}$ and EDS with the resolution for MnKa of $133 \mathrm{eV}$.

The adsorption of $\mathrm{Pb}$ (II) ions was investigated for wastewater having $p \mathrm{H} 3$ by adding $\mathrm{HCl}$ and $p \mathrm{H}$ 10 by adding $\mathrm{NaOH}$.

The $\mathrm{Pb}$ (II) ions concentrations in $1000 \mathrm{~mL}$ synthetic wastewater were $0.5,1,1.5,2 \mathrm{mg} / \mathrm{L}$. The amounts of $\mathrm{Fe}_{3} \mathrm{O}_{4}$ - chitosan composite tested for wastewater treatment were: $0.05,0.1,0.2 \mathrm{~g}$. The $\mathrm{Pb}$ (II) ions concentration of wastewater was measured during the experiments using the GBC $932 \mathrm{AB}$ plus atomic absorption spectrometer.

\section{Results and discussions}

\subsection{XRD analysis}

X-ray diffraction of the synthesized material indicates the crystalline structure specific to magnetite. The appearance in the diffractogram of the peak at approximately $2 \Theta$ of $20^{\circ}$ indicates the amorphous structure of chitosan (Figure 1) [21]. The chitosan structure is influenced by its treatment process (precipitation, dissolving and drying) [21]. The $\mathrm{Fe}_{3} \mathrm{O}_{4}$ specific Miller (hkl) indices correspond to (220), (311), (400), (422), (511) and (440).

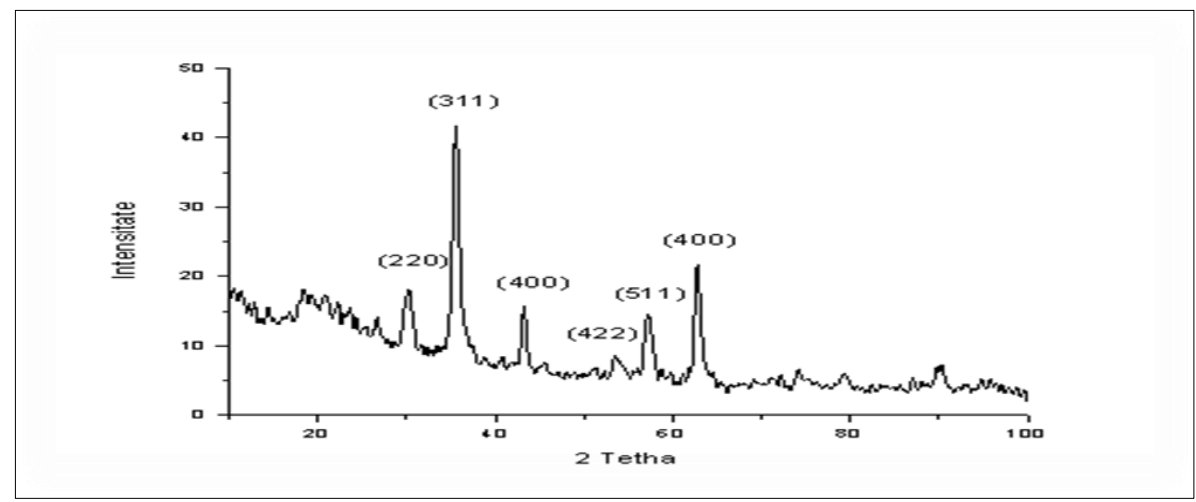

Figure 1. X-ray diffractogram of $\mathrm{Fe}_{3} \mathrm{O}_{4}$ - chitosan composite

\subsection{SEM analysis}

The morphological aspect of the samples was studied by SEM analysis which indicates a agglomeration tendency of $\mathrm{Fe}_{3} \mathrm{O}_{4}$ nanoparticles due to the magnetic properties. The magnifications of about 120000x and 300000x respectively confirm the homogeneity of the particles, the small size in the order of nanometers and their tendency to agglomerate (Figure 2).
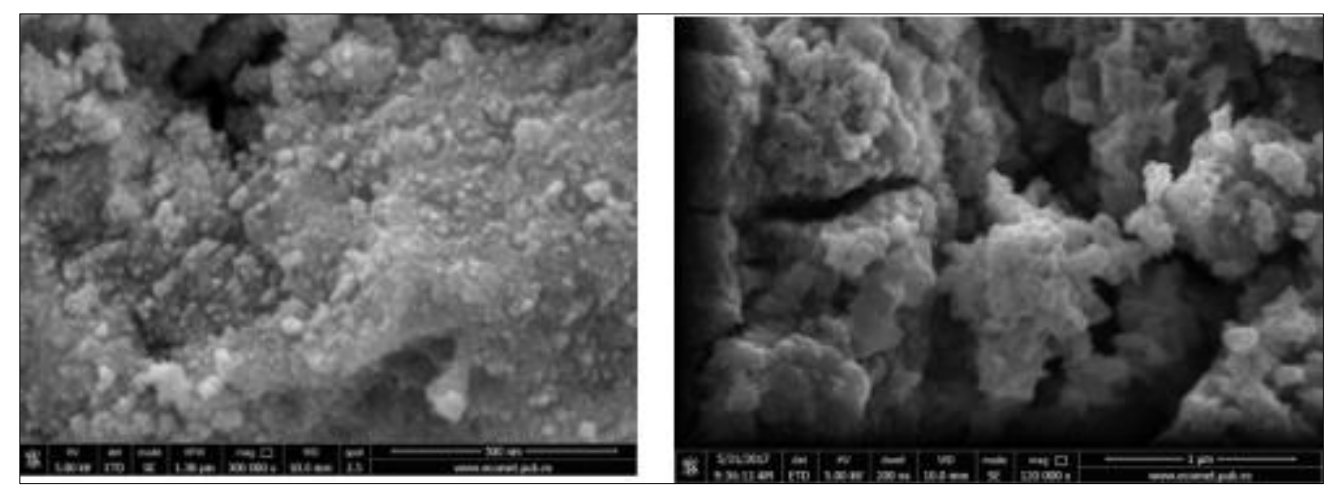

Figure 2. SEM analysis of the $\mathrm{Fe}_{3} \mathrm{O}_{4}$ - chitosan composite 


\subsection{Adsorption experiments}

The investigation of $\mathrm{Fe}_{3} \mathrm{O}_{4}$ - chitosan nanocomposite adsorbent capacity was tested for depollution of wastewater having four concentrations of lead ions in the wastewater: $0.50,1.00,1.50$ and $2.00 \mathrm{mg} / \mathrm{L}$. The experiments were done for acid and basic wastewater.

For the acidic wastewater the results are shown in Figures 3, 4 and 5.

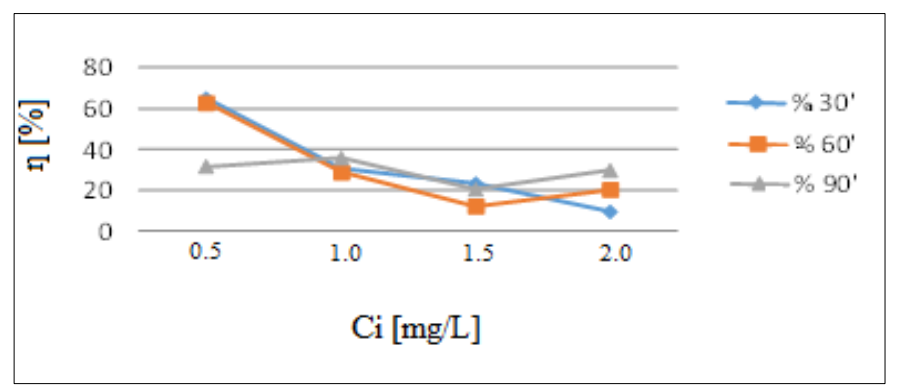

Figure 3. Lead ions removal efficiency for

$0.05 \mathrm{~g} \mathrm{Fe}_{3} \mathrm{O}_{4}-$ chitosan composite and $p \mathrm{H} 3$

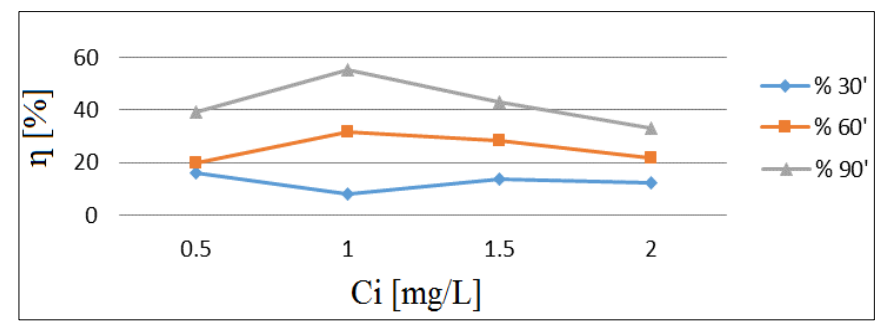

Figure 4. Lead removal efficiency for $0.1 \mathrm{~g} \mathrm{Fe}_{3} \mathrm{O}_{4}$ - chitosan composite

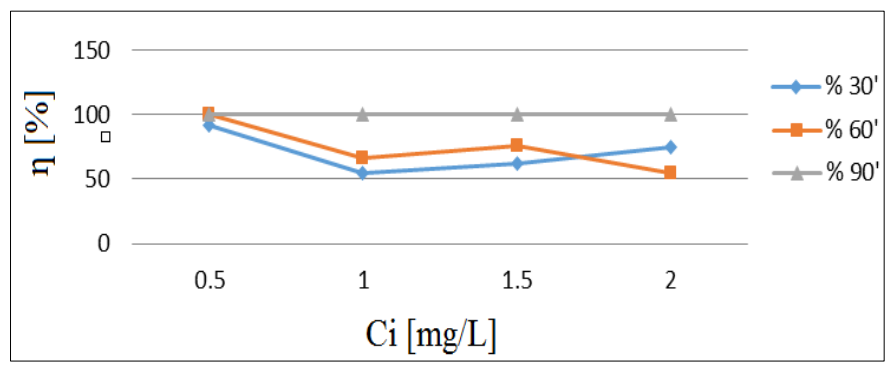

Figure 5. Lead removal efficiency for

$0.2 \mathrm{~g} \mathrm{Fe}_{3} \mathrm{O}_{4}$ - chitosan composite

The results obtained for the acidic wastewater show that the highest lead removal efficiency was obtained in the case of using $0.2 \mathrm{~g} \mathrm{Fe}_{3} \mathrm{O}_{4}$-chitosan nanocomposite, the yield being $100 \%$ for concentrations of $0.5,1,1.5,2 \mathrm{mg} / \mathrm{L} \mathrm{Pb}$ (II) after $90 \mathrm{~min}$ of investigation. This maximum efficiency represents a more efficient wastewater treatment comparing with other research, which revealed the obtaining of a treatment efficiency of about 30\%. [22].

For the wastewater having the $p \mathrm{H}$ in the basic range, the results are shown in Figures 6,7 and 8 .

The results of wastewater treatment yield reach $100 \%$ treatment efficiencies compared to that presented in other scientific literature, which showed a yield of approximately $90 \%$ [22]. 


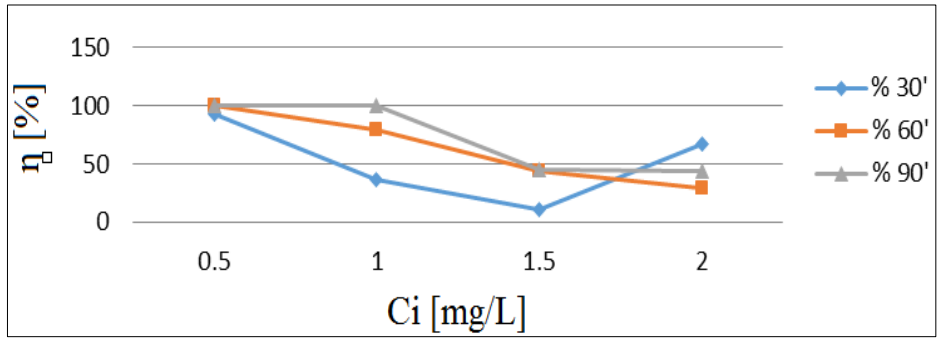

Figure 6. Lead removal efficiency

for $0.05 \mathrm{~g} \mathrm{Fe}_{3} \mathrm{O}_{4}$ - chitosan composite

For the investigation done for basic wastewater, $0.05 \mathrm{~g} \mathrm{Fe}_{3} \mathrm{O}_{4}$ - chitosan composite adsorbent, at concentrations of 0.5 and $1 \mathrm{mg} / \mathrm{L} \mathrm{Pb}^{2+}$, the yield obtained was $100 \%$ after $90 \mathrm{~min}$.

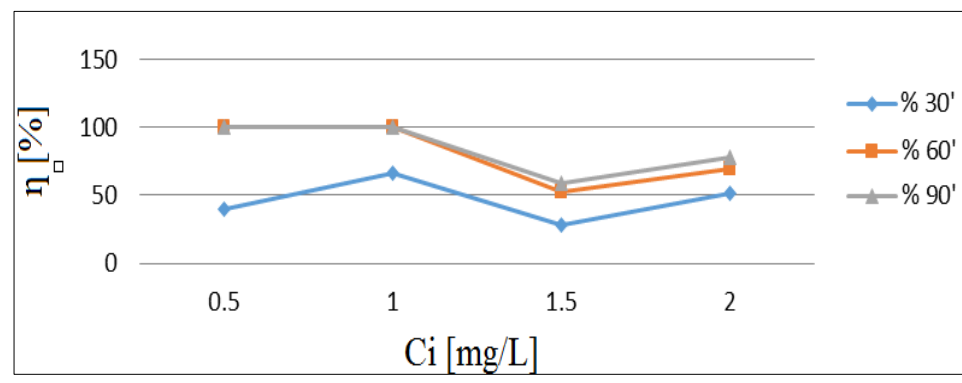

Figure 7. Lead removal efficiency for $0.1 \mathrm{~g} \mathrm{Fe}_{3} \mathrm{O}_{4}$ - chitosan composite

In the case of using $0.1 \mathrm{~g} \mathrm{Fe}_{3} \mathrm{O}_{4}$ - chitosan composite adsorbent, for both 0.5 and $1 \mathrm{mg} / \mathrm{L} \mathrm{Pb}^{2+}$ ions in wastewater, the yield was $100 \%$ after 60 and 90 min.

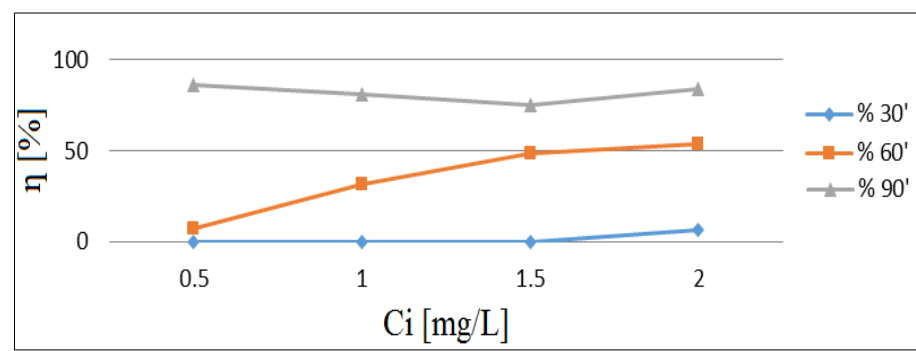

Figure 8. Lead removal efficiency

for $0.2 \mathrm{~g} \mathrm{Fe}_{3} \mathrm{O}_{4}$ - chitosan composite

Also in the case of using $0.2 \mathrm{~g}$ of $\mathrm{Fe}_{3} \mathrm{O}_{4}$ - chitosan composite, the highest wastewater treatment yield (aprox. 90\%) was obtained for $0.5 \mathrm{mg} / \mathrm{L}$ of the $\mathrm{Pb}^{2+}$ ions, after $90 \mathrm{~min}$ of investigation.

\section{Conclusions}

It has been shown that the $\mathrm{Fe}_{3} \mathrm{O}_{4}$ - chitosan nanocomposite is a good adsorbent for the removal of lead ions from wastewater.

This study show that for basic wastewater, the $100 \%$ treatment efficiency was obtained for a concentration of lead ions up to $1 \mathrm{mg} / \mathrm{L}$ and quantities of 0.05 and $0.1 \mathrm{~g}$ of $\mathrm{Fe}_{3} \mathrm{O}_{4}-$ chitosan nanocomposite adsorbent. For acidic wastewater, the maximum treatment efficiency was obtained for a lead ions concentration up to $2 \mathrm{mg} / \mathrm{L}$ and $0.2 \mathrm{~g}$ of $\mathrm{Fe}_{3} \mathrm{O}_{4}$ - chitosan composite. The contact time needed to reach maximum wastewater treatment efficiency was only $90 \mathrm{~min}$. 


\section{References}

1.YANG, H. H., ZHANG, S.Q., CHEN, X. L., ZHUANG, Z. X., XU, J. G., WANG, X. R., MagnetiteContaining Spherical Silica Nanoparticles for Biocatalysis and Bioseparations, Anal. Chem., 76(5), 2004, 1316-1321.

2.AGUILAR-ARTEAGA, K., RODRIGUEZ, J. A., BARRADO E., Magnetic solids in analytical chemistry: a review, Anal Chim Acta, 674, 2010, 157-165.

3.CAMPOS, E. A., PINTO, D. V. B. S., DE OLIVEIRA, J. I. S., DA COSTA MATTOS, E., DE CÁSSIA LAZZARINI DUTRA, R., Synthesis, Characterization and Applications of Iron Oxide Nanoparticles - a Short Review, J. Aerosp. Technol. Manag., São José dos Campos, 7(3), 2015, 267276.

4.GE, H.C., WANG, S.K., Thermal preparation of chitosan-acrylic acidsuperabsorbent: optimization, characteristic and water absorbency, Carbohydr. Polym., 113, 2014, 296-303.

5.MORIN-CRINI, N., LICHTFOUSE, E., TORRI, G., CRINI, G., Applications of chitosan in food, pharmaceuticals, medicine, cosmetics, agriculture, textiles, pulp and paper, biotechnology, and environmental chemistry, Environmental Chemistry Letters, 17, 2019, 1667-1692.

6.FREY, N.A., PENG, S., CHENG, K., SUN, S.H., Magnetic nanoparticles: synthesis, functionalization, and applications in bioimaging and magnetic energy storage, Chem. Soc. Rev., 38, 2009, 2532-2542.

7.DONADEL, K., FELISBERTO, D. V. M., FÁVERE, T. V., RIGONI, M., BATISTELA, N. J., LARANJEIRA, C. M. M., Synthesis and characterization of the iron oxide magnetic particles coated with chitosan biopolymer, Materials Science and Engineering C, 28, 2008, 509-514

8. TRAN H.V., TRAN L.D., NGUYEN T.N., Preparation of chitosan/magnetite composite beads and their application for removal of $\mathrm{Pb}(\mathrm{II})$ and $\mathrm{Ni}(\mathrm{II})$ from aqueous solution, Materials Science and Engineering C, 30(2), 2010, 304-310.

9.WANG, L.K., VACCARI, D.A., LI, Y., SHAMMAS, N.K., Chapter 5: Chemical Precipitation, Physicochemical Treatment Processes, in: L.K. Wang, Y.T. Hung, N.K. Shammas (Eds.), Humana Press, 3, 2005, 141-197.

10.SRIVASTAVA, V., WENG, C.H., SINGH, V.K., SHARMA, Y.C., Adsorption of nickel ions from aqueous solutions by nano alumina: kinetic, mass transfer, and equilibrium studies, J. Chem. Eng. Data, 56, 2011, 1414-1422.

11.MOTSI, T., ROWSON, N.A., SIMMONS, M.J.H., Adsorption of heavy metals from acid mine drainage by natural zeolite, Int. J. Miner. Process., 92, 2009, 42-48.

12.BÓDALO-SANTOYO, A., GÓMEZ-CARRASCO, J.L., GÓMEZ-GÓMEZ, E., MÁXIMOMARTÍN, F., HIDALGO-MONTESINOS, A.M., Application of reverse osmosis to reduce pollutants present in industrial wastewater, Desalination, 155, 2003, 101-108.

13.WALSH, F.C., READE, G.W., Electrochemical techniques for the treatment of dilute metal-ion solutions, Stud. Environ. Sci., 59, 1994, 3-44.

14.ERSAHIN, M.E., OZGUN, H., DERELI, R.K., OZTURK, I., ROEST, K., VAN LIER, J.B., A review on dynamic membrane filtration: materials, applications and future perspectives, Bioresour. Technol., 122, 2012, 196-206.

15.ZHANG, P., HAHN, H.H., HOFFMANN, E., Different behavior of iron (III) and aluminum(III) salts to coagulate silica particle suspension, Acta Hydrochem. Hydrobiol., 31, 2003, 145-151.

16.RYKOWSKA, I., WASIAK, W., BYRA, J., Extraction of copper ions using silica gel with chemically modified surface, Chem. Pap., 62, 2008, 255-259.

17.WALSH, F.C., READE, G.W., Electrochemical techniques for the treatment of dilute metal-ion solutions, Stud. Environ. Sci., 59, 1994, 3-44.

18.KAVAMURA, V.N., ESPOSITO, E., Biotechnological strategies applied to the decontamination of soils polluted with heavy metals, Biotechnol. Adv., 28, 2010, 61-69.

19.GOGOI, P., THAKUR, J. A., DEVI, R. R., DAS, B., MAJI, K. T., Adsorption of As(V) from contaminated water over chitosan coated magnetite nanoparticle: Equilibrium and kinetics study, Environmental Nanotechnology, Monitoring \& Management, 8, 2017, 297-305. 
20.KHALIL, T. E., ELHUSSEINY, F. A., EL-DISSOUKY, A., IBRAHIM, M. N., Functionalized chitosan nanocomposites for removal of toxic $\mathrm{Cr}$ (VI) from aqueous solution, Reactive and Functional Polymers, 146, 2020, 104407.

21.LASHEEN, M.R., EL-SHERIF, Y. I., TAWFIK, E. M., EL-WAKEEL, S.T., EL-SHAHAT, M.F., Preparation and adsorption properties of nano magnetite chitosan films for heavy metal ions from aqueous solution, Materials Research Bulletin, 80, 2016, 344-350.

22.CHRISTOPHER, F. C., ANBALAGAN, S., KUMAR, P. S., PANNERSELVAM, S. R., VAIDYANATHAN, V. K., Surface adsorption of poisonous $\mathrm{Pb}(\mathrm{II})$ ions from water using chitosan functionalized magnetic nanoparticles, IET Nanobiotehnol., 11(4), 2017, 433-442.

23. COVALIU C., NEAMTU J., GEORGESCU G., MĂLAERU T., CRISTEA C., JITARU I., Synthesis and characterization of ferrites $\left(\mathrm{Fe}_{3} \mathrm{O}_{4} / \mathrm{CuFe}_{2} \mathrm{O}_{4}\right)$ - calcium alginate hybrids for magnetic resonance imaging, Digest Journal of Nanomaterials and Biostructures, 6 (1), 2011, 245 - 252.

$\overline{\text { Manuscript received: } 11.09 .2020}$ 